Małgorzata Gutry-Korycka, Gabriela Gąsowska*

\title{
ALIMENTATION CONDITIONS OF RIVER VALLEYS WITH COMPLEX STRUCTURES
}

\section{INTRODUCTION}

Large rivers with well-developed valleys and distinctly marked terraces, such as the Vistula in its middle course, facilitate complicated water circulation processes resulting from direct hydrodynamic relationship between the river channel and the produced water-bearing strata. In this case, the majority of Pleistocene and Holocene river terraces have the form of sedimentation terraces inlaid in the valley depression. The speed and the scope of the Vistula erosion (terraces) are determined by climatic changes in the consecutive glacial, interglacial and Holocene cycles (Starkel, 1994; Zuchiewicz, 1995).

The Middle Vistula valley, stretching between Warsaw and the mouth of the Bug and the Narew is characterised by a considerable complexity of vertical and horizontal deposits. The sedimentation periods alternating with consecutive stages of river erosion in the Pleistocene and Holocene periods left their mark on the characteristics of alluvial waters; the alimentation of the channel water is related to the deeper hydrogeological structures of the valley structure.

The paper aims to identify the mechanism of water circulation in the alluvia of the Vistula valley and offers an attempt at its quantitative evaluation.

THE HYDROGEOLOGICAL STRUCTURE OF THE VISTULA VALLEY

Within the alluvial valley, two types of underground water can be distinguished: bottom subwaterbank water related to the contemporary alluvia underlying the riverbed and terrace water, which normally remain in hydraulic relationship with the water flowing in the channel.

* Author of M.A. dissertation "The correlation between alluvial water and flooding of the Vistula", 1998. 
Alimentation of alluvial water in the river valley takes place as a result of vertical infiltration from atmospheric precipitation; lateral infiltration from the side tributaries (when the tributary enters the bottom of the main valley to encounter alluvia of greater volume than its own); laterally, as a side tributary of water infiltrating from the adjacent aquifers, from higher sedimentation levels interrelated with the lower layers of the water-bearing formations of the valley bottom, and ascently, i.e. using the underground water rising (frequently from a considerable depth) as a result of the difference in hydrostatic pressure, predominantly through dislocation zones.

It should be expected therefore that the deepest layers of the Vistula valley alluvia should be alimented by the lateral and ascending inflow produced by the drainage of remote underground circulation water.

The valley and the channel of the Vistula intersect the Mazovian Basin, draining aquifers that formed in the Quaternary, Tertiary and even the Cretaceous periods. Macioszczyk (1998) and Bażyński (1996a, b) distinguish three water-bearing stages: Upper Cretaceous-Palaeocene; Oligocene-Miocene and the Quaternary, in addition to two isolating stages: Upper Cretaceous and Upper Miocene-Pliocene.

The multi-aquifer formation of the Upper Cretaceous evolved in fissured limestone, marl, chalk rock, gaize and sand limestone, producing one water-bearing horizon remaining under piezometric pressure (ranging from a dozen to several dozen metres). The piezometric area culmination during high-water stage rises to 140-180 metres above sea level; probably, there is no connection with the Vistula river channel.

The multi-aquifer formation of the Tertiary consists of two levels: Oligocene and Miocene (Bażyński, 1997). The Oligocene water-bearing stratum is related to glauconite sands composed of fine sands interbedded with muds and silts. The Oligocene sands are considerably washed (Macioszczyk, 1996). The sands, with thickness ranging between 11 and 60 metres, occur at a depth of 80-200 metres, while the aquifer formations normally account for three fourths of their thickness. Within the Praga terrace (right bank of the Vistula) the Artesian pressure of Oligocene water at the beginning of exploitation (until the end of the $19^{\text {th }}$ century) was a dozen metres above the ground (approximately 85 metres above sea level). The Oligocene aquifer lost its partially Artesian character due to exploitation, and its water table is settled several metres below the bottom of the Vistula. Kazimierski (1997) discovered a steady realimentation of the Oligocene stratum (Oligocene recharge). However, on the right bank of the Vistula, in the floodplain terraces, this water table still remains below the ground level.

The Miocene formation evolved on Oligocene deposits in the interbedding layers of fine sands with clays, loams and brown coals of the Miocene brown coal formation, with the exception of erosion windows (Sarnacka, 1990; Macioszczyk, 1986, 1996; Bażyński, 1996b). Their thickness varies from 50 to 100 metres, and strata of poorly permeable insertions are not continuous. For this reason, a direct or indirect hydraulic connection occurs between 


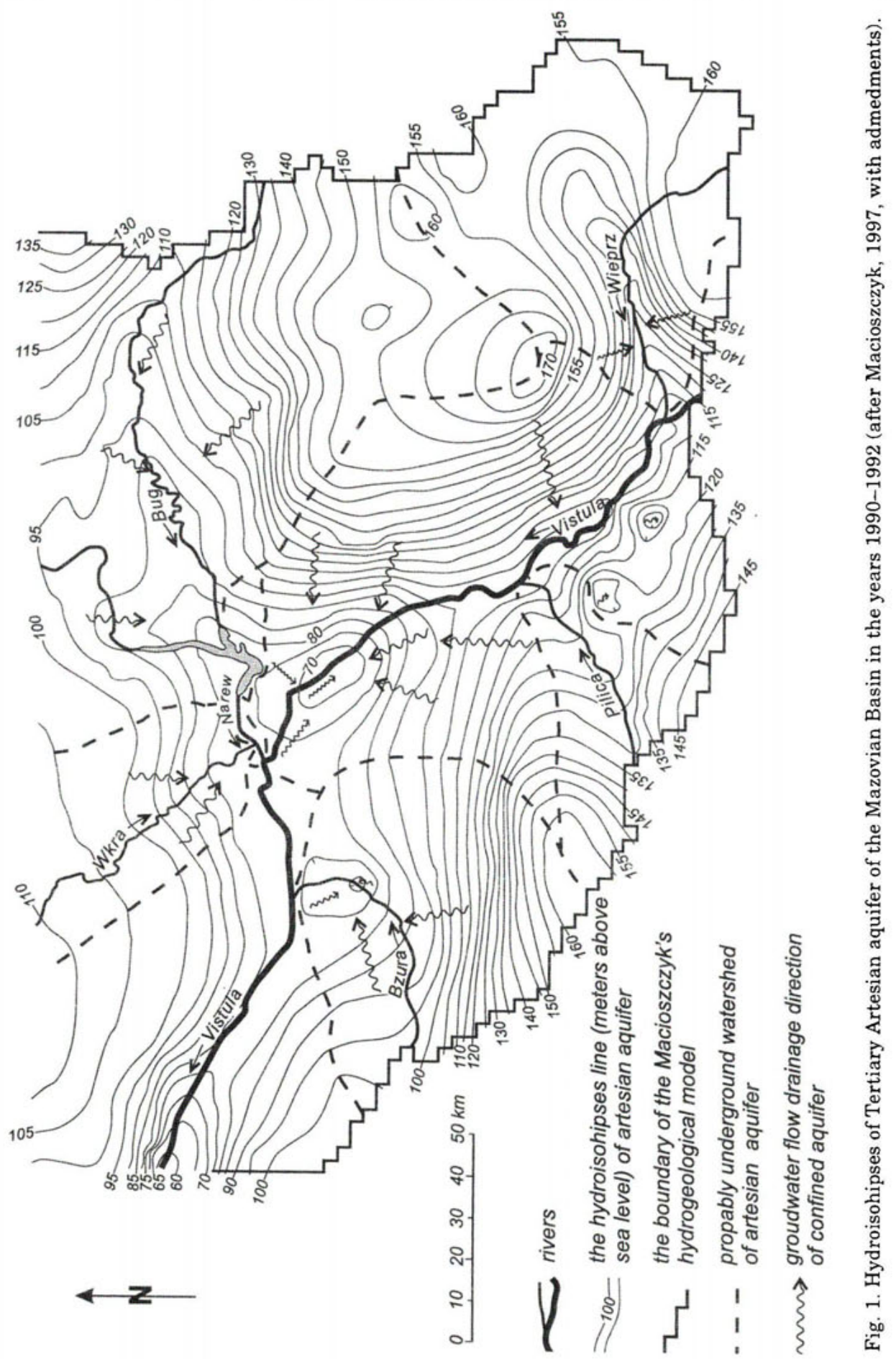


the water-bearing stages. The listed aquifers are, as a rule, treated collectively (Macioszczyk, 1997). The spatial distribution of isolines of this Tertiary aquifer, characterised by piezometric pressure (100-150 metres) is shown in Figure 1.

The Quaternary aquifers which evolved during the Riss and Mindel glaciation (Sarnacka, 1990) make up one aquifer of considerable thickness (40-80 metres), highly varied in the valley and terraces. The water table is the most shallow in sand and alluvial soil deposits in the terraces (both meadow and floodplain ones); it is relatively deeper (2-4 metres) in spreads of aqua-glacial sands, while that in dune sands (meadow terrace) is even deeper (2-20 metres).

In the scarp zone of the high plain, the Quaternary aquifer remains at a lower level due to the strong, forced drainage manifested by leakage of groundwater, springs and trickling of groundwater without visible surface outflow that erodes the scarp and aliments the valley alluvia (Sarnacka, 1990; Biernacki, 1990). This water remains in hydraulic connection with the Vistula alluvia, and has the nature of free water table, testifying to deep subterranean drainage (Fig. 2).

\section{THE WATER CIRCULATION MECHANISM IN THE VISTULA VALLEY}

The drainage of underground water is possible owing to the hydraulic slope, that is, the inclination of the water table towards the erosion base which is the valley and the river band of the Vistula. It is dependent on the differentiation of the vertical and horizontal infiltration of the overlaying and water-bearing strata.

The infiltration properties of the deposits filling the Vistula valley are good and very good. In the alluvia, gravels, sandy gravels, coarse-grained sands with permeability coefficient $\mathrm{k}=10^{-3}(\mathrm{~m} / \mathrm{s})$ prevail, while mediumgrained sands $\mathrm{k}=10^{-4}(\mathrm{~m} / \mathrm{s})$ are less common. In floodplain terraces, locally friable sands of low permeability, clayey sands and loams of weaker filtration $\mathrm{k}=10^{-5}-10^{-6}(\mathrm{~m} / \mathrm{s})$ prevail. Only sporadically, poorly permeable clays, silts and muds $-\mathrm{k}=10^{-6}(\mathrm{~m} / \mathrm{s})$ can be found.

The mechanism of water circulation in the valley is complex; it depends on a number of factors and has not, as yet, been fully explored. The authors opt for the hypothesis that the Vistula has developed a permanent equilibrium of draining the water-bearing horizons, and during high-water stages it periodically aliments the underground water. This invites the question on the course of the valley drainage in time and in space; whether the hydraulic pressure of the high-water wave is higher than the piezometric pressure under the river channel (pressure gradient). Another question that may be posed at this point is whether the high-water invariably "squeezes down" (restrains) the downflow of underground Artesian water to the river channel and to the valley. If the answer is positive a considerable drift- 


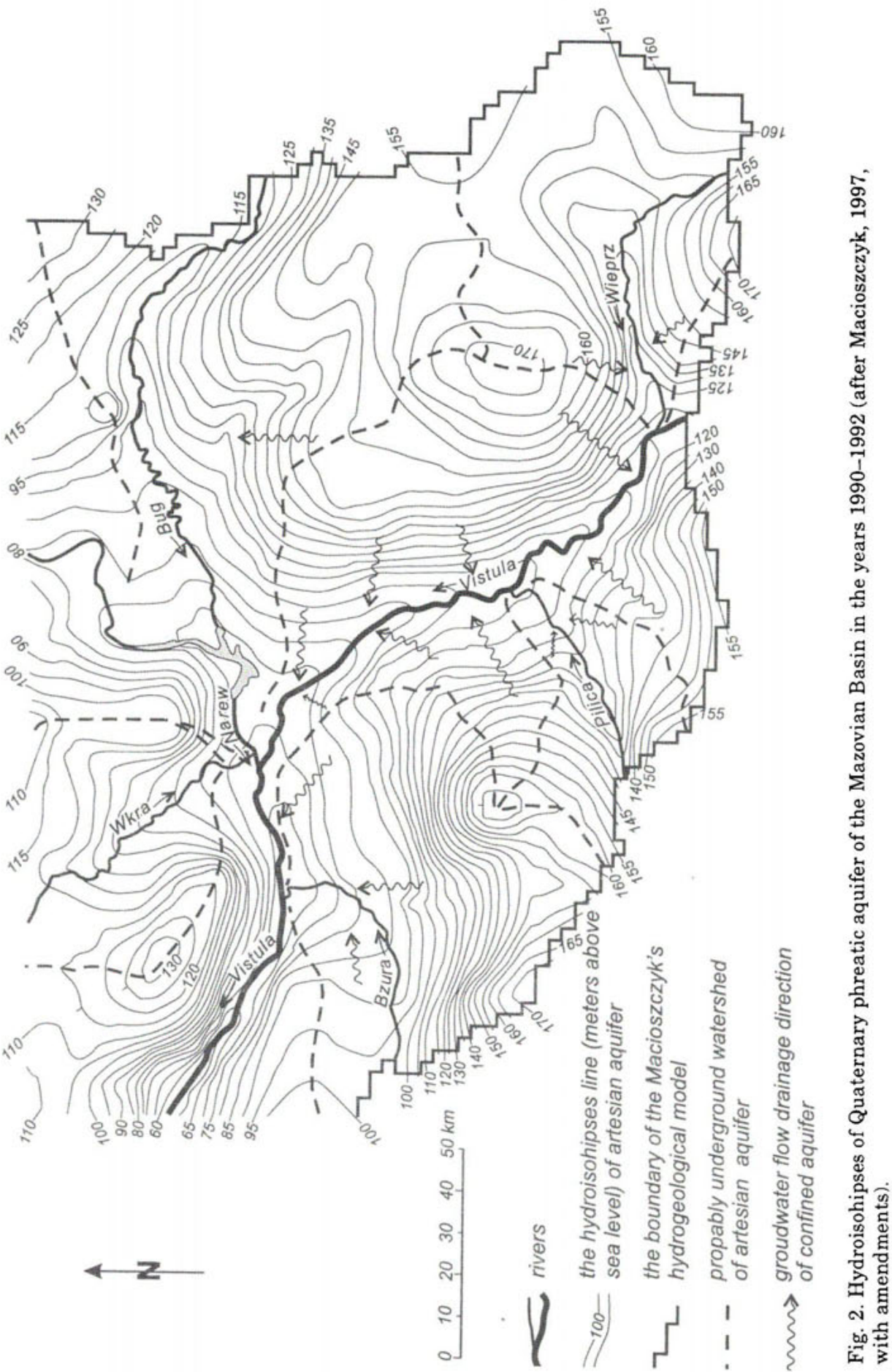


damming of water flowing down from the aquifer should be expected, a process which might affect the anomalies of water flood runoff.

\section{GROUNDWATER DRAINAGE IN THE RIVER VALLEY}

The drainage of alluvial waters is the strongest in the scarp zone, where hydraulic gradients are the highest (Fig. 3a-g). The variable height of the terraces and their asymmetry lead to differences in lateral falls of alluvial water table and filtration conditions. The velocity of lateral filtration at a distance of two kilometres from the river channel, calculated according to the parameters (Table 1) and Darcy's equation, oscillated between $0.3 \mathrm{~km} / \mathrm{h}$ (cross-section 3e) to $5.0 \mathrm{~km} / \mathrm{h}$ (cross-section 3a). In the southern part of the valley (Ciszyca), the longitudinal gradient of the channel is the highest $(0.37 \%$ ) , while the lateral gradient of alluvial water is very small $(0.0014 \%)$, which emphasises the distinctly draining nature of the valley. Down the river, the hydraulic gradient of alluvial water gradually diminishes (Biernacki, 1990). An abrupt, nearly seventeenfold lowering of the velocity of lateral filtration can be observed below the Wilanówka (left tributary), where both the river channel and the valley considerably narrow, and the banks of the Vistula are regulated.

In the northern part of the valley, despite increased gradient of alluvial water in some places, the filtration is less favourable $(=1 \mathrm{~km} / \mathrm{h})$.

The research conducted by Macioszczyk (1997) indicates that the river channel drains not only the Quaternary aquifer, with which it is in hydraulic connection, but also the Artesian aquifers: the Tertiary and Quaternary ones, remaining under pressure (Figs. 1 and 2).

The overall picture of the hydroisohipses of the Tertiary aquifer is similar to the water table pattern of the Quaternary stratum. What is distinctly manifested is the draining nature of high plains through the valleys, confirming the connection with remote circulation underground water.

The distribution of differences in the ordinates of the Quaternary and Tertiary water table is significant. In the high plain zone, the Quaternary water table is situated above the Tertiary water table, while in the river valley zone the situation is opposite. Distinct deviations can be found in those valley sections where, as a result of water intake, the Tertiary stage has been depressed (Figs. 1 and 2), which is manifest in the area of the Warsaw agglomeration. Macioszczyk (1997) discovered that the Quaternary water table occurs 20-30 metres above the Tertiary water table. Such a hydrogeological pattern justifies the conclusion that in the valleys of the Vistula and its major tributaries (Pilica, Narew, Bzura), the Tertiary stage water aliments the Quaternary stage. Thus, those horizons meet in them, and release (discharge) of piezometric pressure occurs. An indispensable pre-condition for such merger is varied permeability of Pliocene deposits (Macioszczyk, 1988, 1996, 1997). In addition, Kazimierski (1997) and 
Macioszczyk (1997) agree with the opinion that the Pliocene, composed of silt fraction in one third (silts, 30\% - dusty silts, and the remaining $40 \%$ - dust, dusty, fine-grained and coarse-grained sands) affects the velocity variations of the vertical filtration. Thus, Pliocene silts, owing to their lumpy structure, can carry water due to the existing differences in hydraulic dynamic pressure (Macioszczyk, 1997). The filtration coefficient $k$ for these formations ranges between $10^{-11}$ to $10^{-8}(\mathrm{~m} / \mathrm{s})$. Even with such low values and one-metre difference in the water level, the intensity of water filtration through the Pliocene fill reaches $50 \mathrm{~m}^{3} / \mathrm{d} / \mathrm{km}^{2}$ (Macioszczyk, 1997). The hydroisohipse maps (Figs. 1 and 2) clearly indicate that the Tertiary water table in the valley of the Vistula, the Bzura and the Narew lies higher, and in the more shallow water-bearing horizons gradually lowers. This forces the saturation of water through the isolating, poorly permeable rocks upwards, to the phreatic aquifer and to the river as the basis of regional drainage. Both the Tertiary and the Quaternary water table gradients in the analysed section of the Vistula valley (respectively $0.00035 \%$ and $<0.0003 \%$ ) prove that the Vistula valley and the related Bzura, Narew and Bug valleys constitute links in the drainage of hydrogeological multi-layer systems.

\section{FILTRATION OF RIVER WATER TO ALLUVIAL WATER}

During high-water stages, the drainage direction is reversed to promote bank filtration from the river channel. This process consists in water permeating through the banks as a result of water damming or lowering underground water below its normal level. As a rule, it lasts for a short time (several days) during high-water stages caused by precipitation or ice jams. The pre-condition for bank filtration is the rising of water above the underground water table, which leads to the reversal of the fall and generates filtration of water to the valley alluvia. As a result, underground water is lifted and the runoff of water flowing down into the valley from the high plain is restrained, thus causing secondary inundation of the valley and the terraces.

An analysis of the progress of high-water stages in the valley and alluvial water on the analysed section of the Vistula was carried out in the years 1969-1983 by comparing the ordinates of the table water in hydrological profiles with the position of the underground water table (measurement units of the IMWM - Institute of Meteorology and Water Management). The selected measurement profiles represent the dynamics of alluvial water during high-water stage at the lower and the higher floodplain terraces, at varying distances from the river channel. This analysis definitely proves that high-water stages of the Vistula (2-4 metres) are matched by an average rise of alluvial water between 0.5 and 1.0 metre. However, the duration of the alluvial high-water stages and their rhythm in different years 
has varied. In the meadow terrace zone, the rising of the underground water table occurs almost simultaneously with the high-water wave of the Vistula (Łomianki Dolne, Kępa Tarchomińska, Kliczyn). The longer the distance from the river channel, the more delayed the reaction of alluvial water to the progress of the high-water wave (Łomianki Dolne, Anusin, Ciszyca).

The valley structure of the analysed section of the Vistula does not give rise to the hypothesis on significant lithological barriers hindering the filtration of river channel water. In addition, the range of influence of high-water stages on alluvial water depends on the lateral gradient of underground water forced by the hipsometry of the floodplain and meadow terraces.

It is the duration and stages, not height, of the high-water that exerts the dominant influence on the river bank filtration, which was evidenced in June 1981 (Fig. 4) within the floodplain terrace located approximately two kilometres from the river channel (Anusin). The pre-condition for the occurrence of the river channel filtration to the valley alluvia is reaching the Vistula stage value above the underground water table (Fig. 4). The biggest river channel filtration, lasting 50 days, occurred in 1981 (in the years 1980, 1982, 1983 it oscillated between 14 and 35 days) and reached the maximum range of two kilometres in Kliczyn and Anusin, and 1.5 kilometres in Łomianki and Kępa Tarchomińska. It should also be observed that the "irrigation" of alluvial water occurred at varying stages of the alluvial water table in the period preceding the high- water stage (Fig. 4). The marginal values marking the beginning of filtration in the southern section of the valley in individual years ranged between 83.2 and 86 metres above sea level ( $~ 3.0$ metres), while in the northern section they fluctuated from 74.7 to 77 metres above sea level ( $\sim 2.3$ metres $)$.

\section{THE QUANTITATIVE EVALUATION OF THE RIVER BAND FILTRATION TO ALLUVIAL WATER}

The flooding of June and July 1997 could be easily observed in the analysed part of the valley. At that time, the first wave representing the highest culmination and the three following waves caused by heavy rainfall were distinctly marked. This was accompanied by a considerable rise of the alluvial water, which was captured thanks to the authors' measurements of the water table in household wells (Zawady) taken every hour, which is illustrated by Fig. 5 (Gąsowska, 1998). At that time, the rise of terrace alluvial water occurred in two stages. Subsequently, the alluvial water stages changed more slowly than the river itself (due to the resistance of the substratum), but they were higher in the valley than the Vistula stages in the Nadwilanówka profile. Starting from July 22, the table of the Vistula and of the alluvial water began to rise almost simultaneously (Fig. 5). The closer the distance to the high plain scarp, the weaker the reaction of alluvial water to filtration. The water stages of the Vistula river channel 


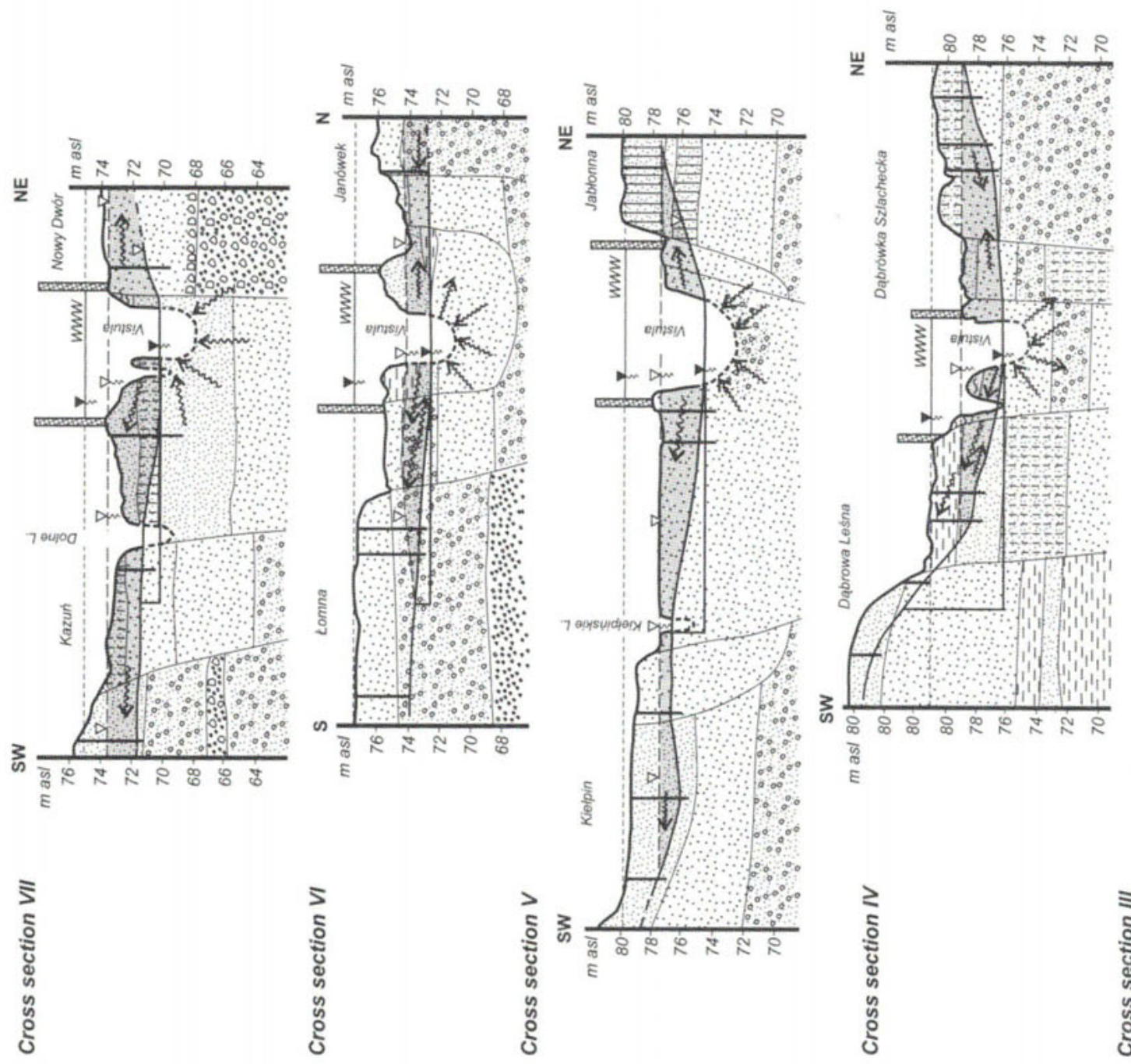


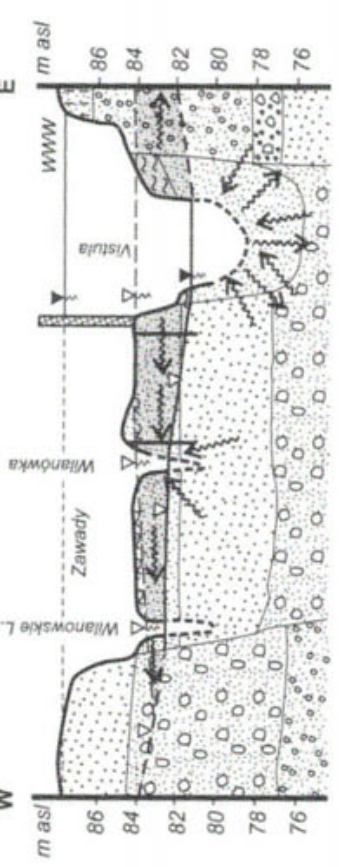

ш

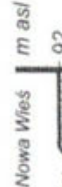
\%

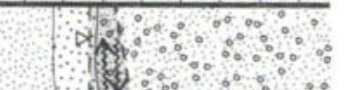

.
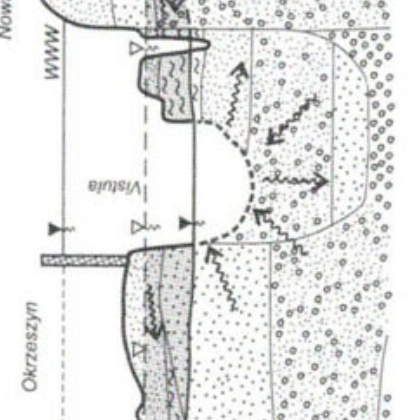$$
\text { exp }
$$ 



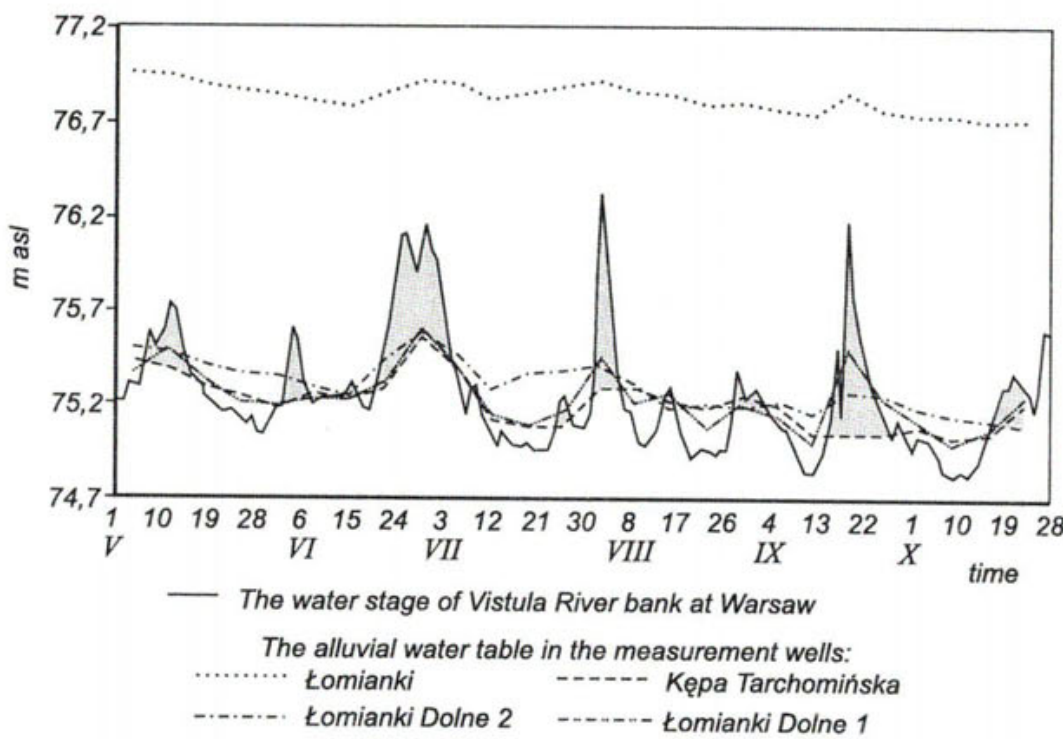

a

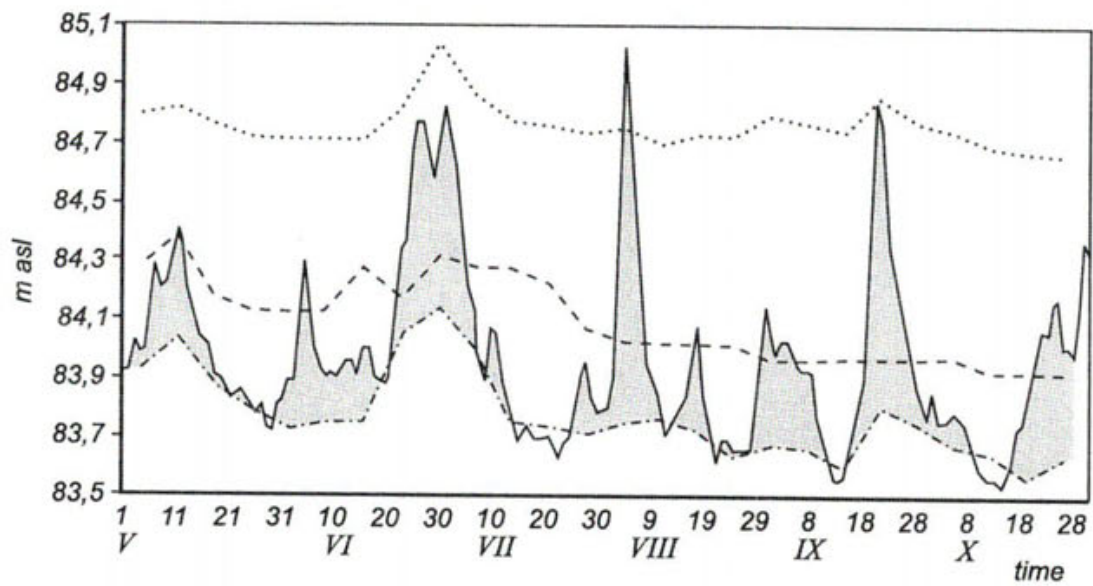

- The water stage of Vistula River bank at Nadwilanówka

The alluvial water table in the measurement wells:

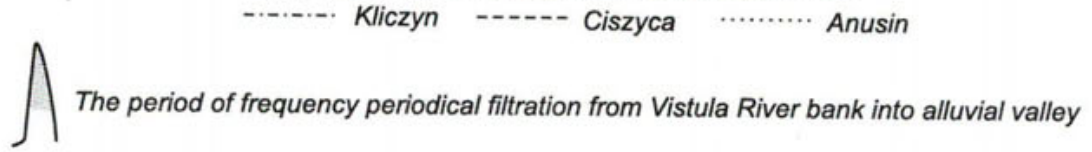

Fig. 4. Water stages of the Vistula and alluvial water tables in the valley (a-d) during selected floodings in the years 1980-1983 with river channel filtration.

$\mathrm{a}-1 \mathrm{~V}-31$ X 1980, b- 1 V-31 X 1981, c - 1 V-31 X 1982, d-1 V-31 X 1983 


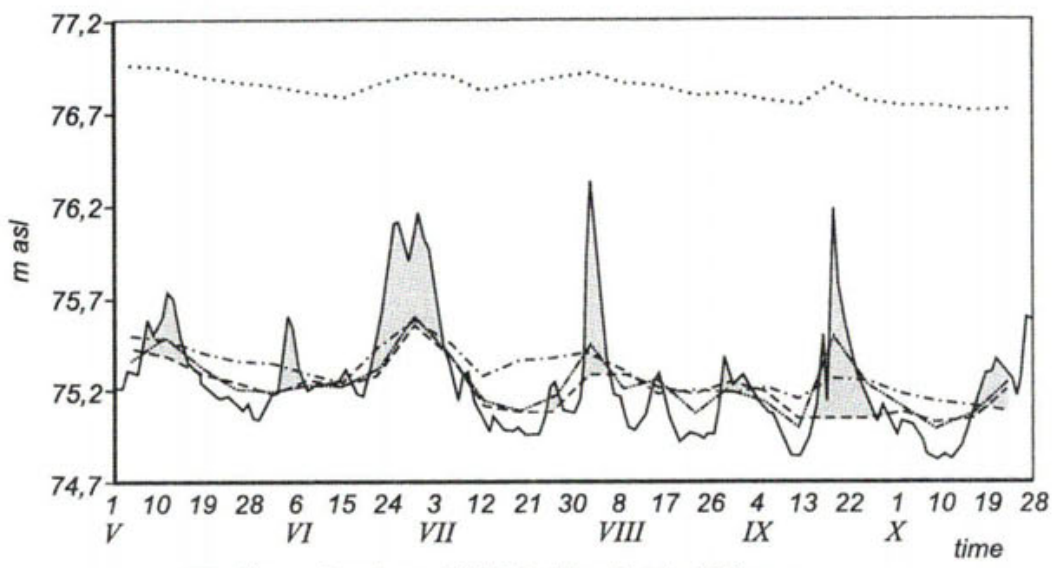

- The water stage of Vistula River bank at Warsaw

The alluvial water table in the measurement wells:

......... Łomianki Kępa Tarchomińska

....... Łomianki Dolne 2 .......- Łomianki Dolne 1

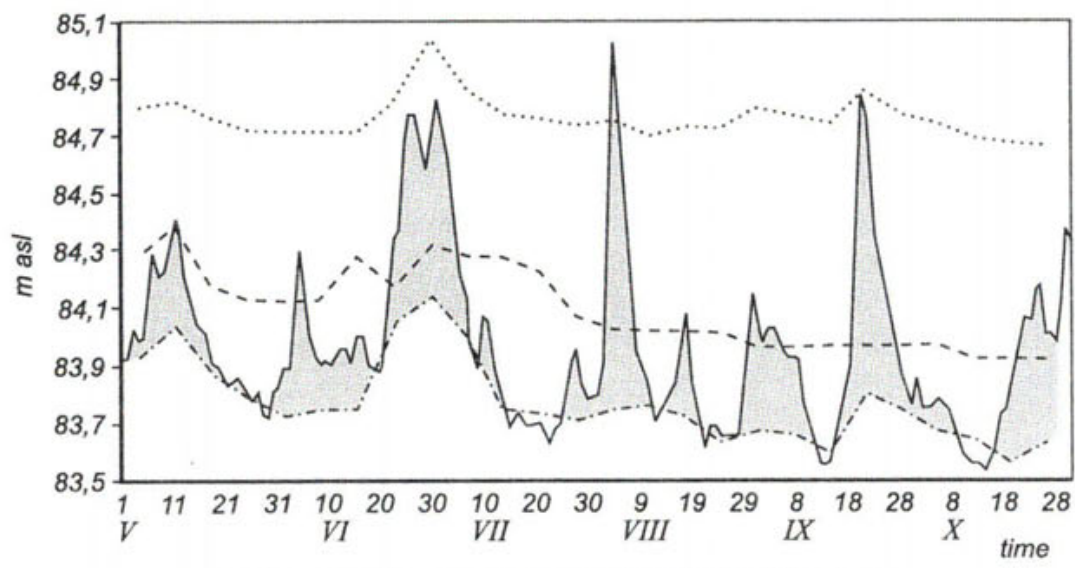

- The water stage of Vistula River bank at Nadwilanówka

The alluvial water table in the measurement wells:

-..... Kliczyn -...- Ciszyca .......... Anusin

$\int$ The period of frequency periodical filtration from Vistula River bank into alluvial valley

during the flood-wave rise faster than the alluvial water stages in the river valley. The rhythm of its water table depends on the distance from the river channel, while the delay was 48 hours within the floodplain terrace located one kilometre from the left bank.

The Vistula high-water stage in April 1998 was $668 \mathrm{~cm}(18 \mathrm{~cm})$ above the alert stage (Mierkiewicz, Sasim, 1998) and was synchronous with the 


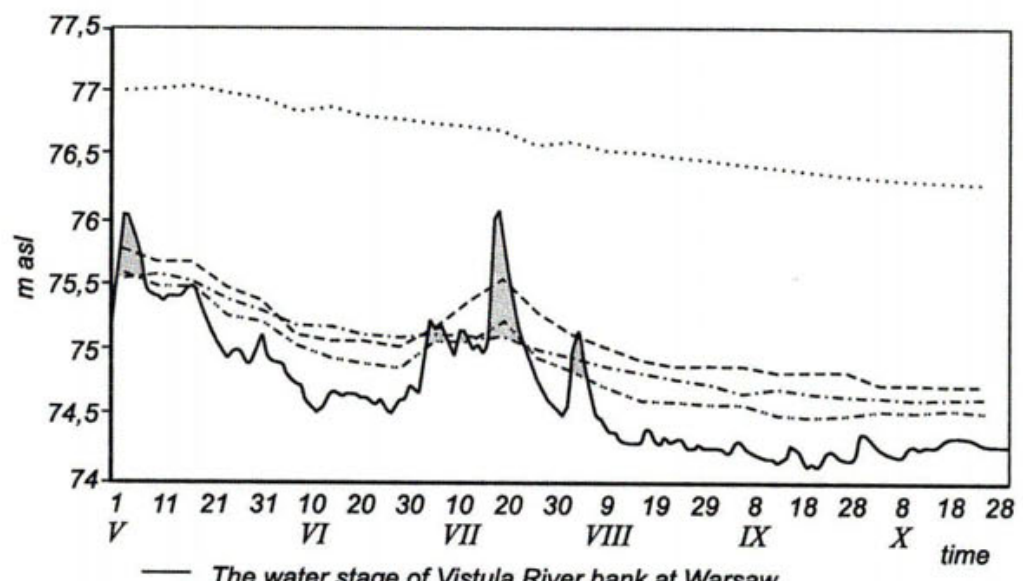

- The water stage of Vistula River bank at Warsaw

The alluvial water table in the measurement wells:

Łomianki

-...... Łomianki Dolne 2 -....--- Łomianki Dolne 1

--- Kępa Tarchomińska

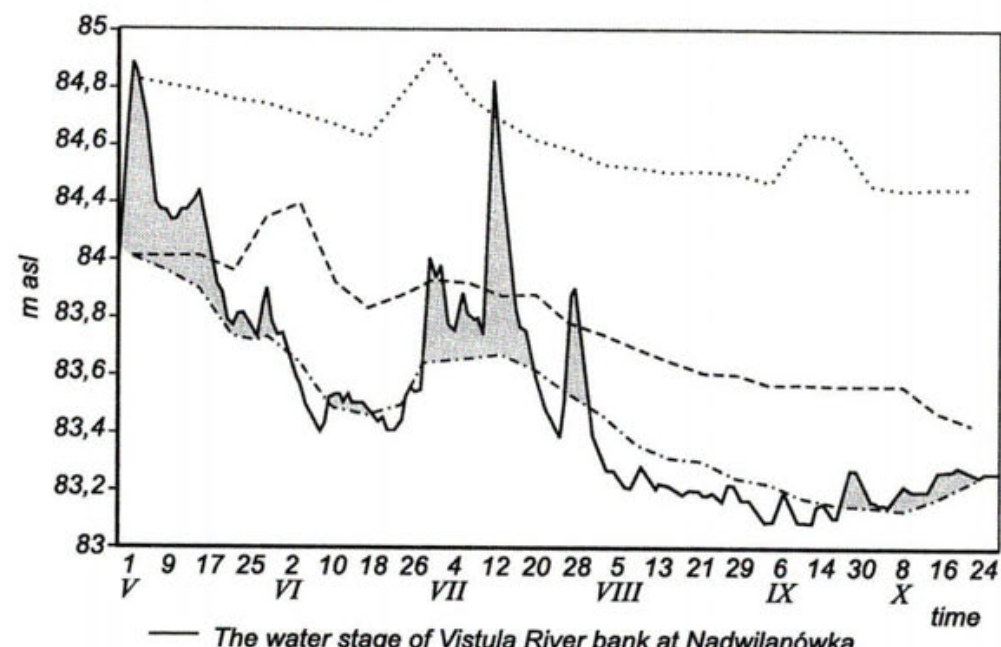

The water stage of Vistula River bank at Nadwilanówka

The alluvial water table in the measurement wells:

-...... Kliczyn -..-. Ciszyca .......... Anusin

\The period of frequency periodical filtration from Vistula River bank into alluvial valley

culmination in the Nadwilanówka profile. On the other hand, a 48-hour delay was recorded in Wyszogród in addition to wave flattening. The flooding produced considerable rise of alluvial water, reaching over one kilometre from the river channel (Łomianki), while in Nowy Dwór (the right bank) the terrace water rose over $60 \mathrm{~cm}$, which represented a delay of 48 hours. 


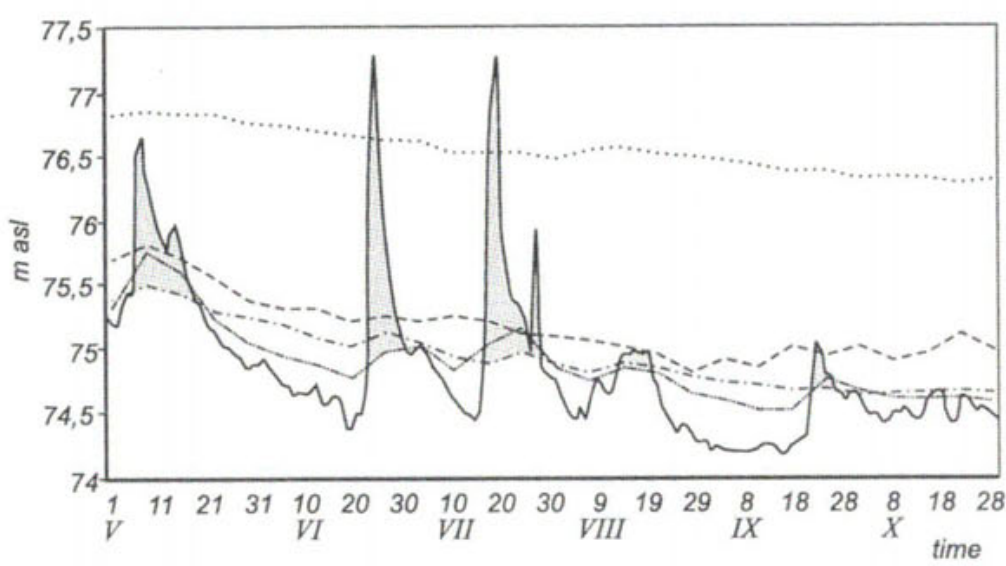

- The water stage of Vistula River bank at Warsaw

The alluvial water table in the measurement wells:

........... Łomianki -...- Kępa Tarchomińska

...... Łomianki Dolne 2 ....... Łomianki Dolne 1

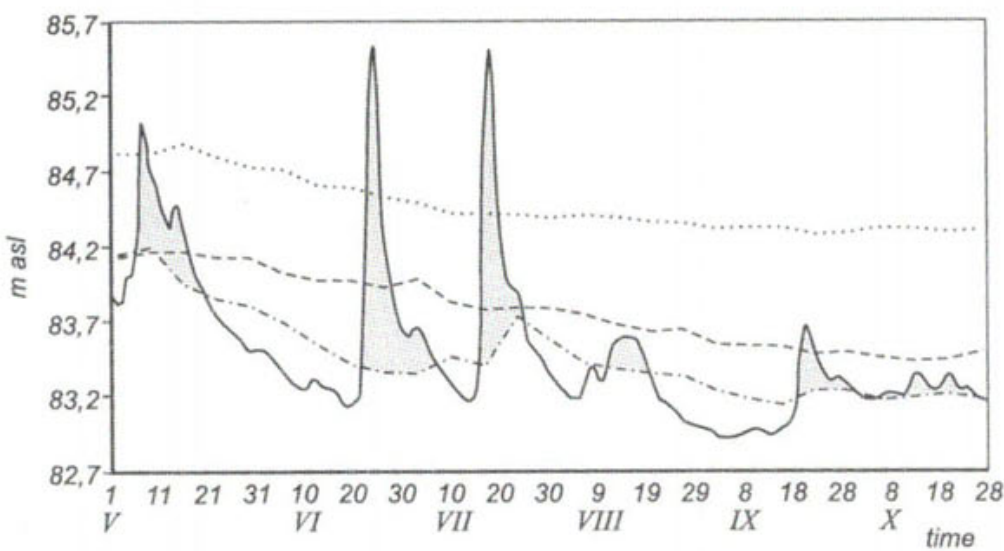

- The water stage of Vistula River bank at Nadwilanówka

The alluvial water table in the measurement wells:

Kliczyn

-...- Ciszyca

Anusin

The period of frequency periodical filtration from Vistula River bank into alluvial valley

A question may be posed whether the extent of the river channel filtration to the valley alluvia could be estimated. Skibniewski (1959) presented a simplified method of assessing river channel filtration using the following pattern: during the flooding, the river water filters to both banks of the valley, moistening the substratum in the triangle-like shape, the basis of the triangle being the range of water stage oscillations in the period pre- 


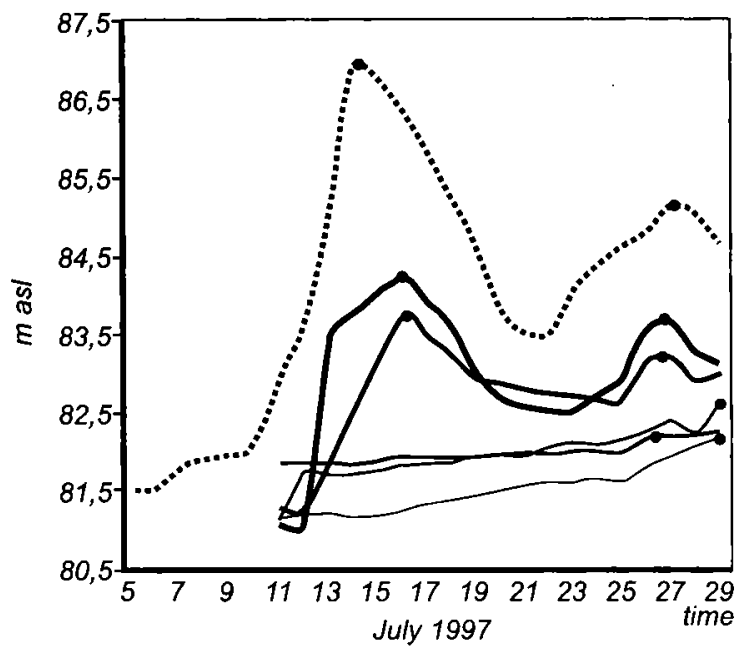

The alluvial water table in the measurement wells:

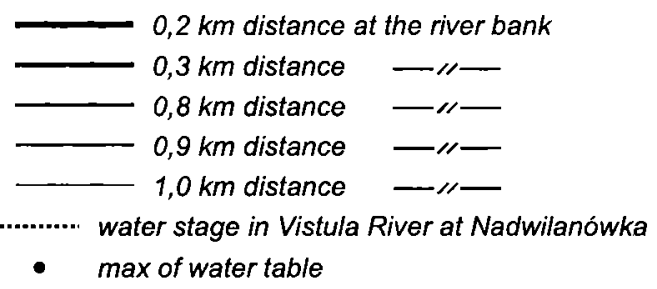

Fig. 5. Water stages of the Vistula and groundwater tables in valley alluvia in Zawady village during the flood of July 11-29, 1997 (after Gąsowska, 1998).

ceding and following the flooding, while its height $(\Delta h)$ is determined by the distance $(l)$ of water filtration into the valley. Naturally, the range of filtration can vary for the two banks of the river. Thus, the area of the triangle is $1 / 2 \Delta h \cdot l$.

Approximate momentary water retention on a given section of the river $(L)$, i.e. the volume $(V)$ of the water filtering into the alluvia during the flooding can be calculated using the equation:

$$
V=1 / 2 \cdot W \cdot \Delta h \cdot l \cdot L
$$

where: $W$ is the coefficient of the total aquatic volume of alluvial formations (terraces).

At this point, let us analyse the progress of the 1997 year flooding on the 80-kilometre long section of the river valley. Then, the maximum water stage was 86.9 metres above sea level, and prior to the flooding -81.5 metres, which corresponds to the amplitude of $\Delta h=4.8$ metres. The adopted coefficient of the total aquatic volume of alluvial sands was $0.2-0.48$, of sand gravels - 0.2-0.4 and gravels - 0.26-0.55 (Pazdro, 1983; Myślińska, 1992). 
Table 1.

Velocity of lateral filtration of alluvial water in the Vistula valley by sections $3 a-g$ (based on water table measurement of July 1997)

\begin{tabular}{|c|c|c|c|c|c|c|}
\hline 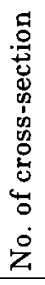 & 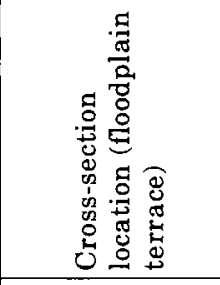 & 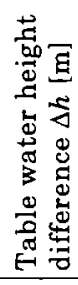 & 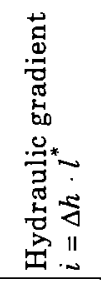 & 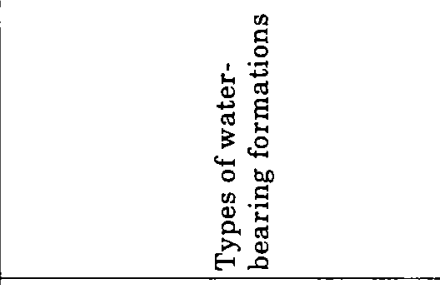 & 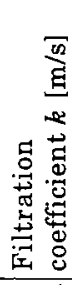 & 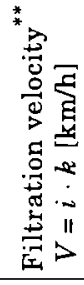 \\
\hline $\mathrm{g}$ & Kazuń & 1.6 & 0.0008 & clayey and coarse-grained sands & $10^{-4}$ & 0.288 \\
\hline $\mathrm{f}$ & Łomna & 1.0 & 0.005 & sand gravels, fine-grained sands & $10^{-3}$ & 1.8 \\
\hline e & Kiełpin & 2.2 & 0.0011 & coarse-grained sands & $10^{-4}$ & 3.96 \\
\hline $\mathrm{d}$ & Dąbrowa Leśna & 6.4 & 0.0032 & fine and coarse-grained sands & $10^{-4}$ & 1.152 \\
\hline c & Zawady & 1.6 & 0.0008 & fine and coarse-grained sands & $10^{-4}$ & 0.288 \\
\hline b & Okrzeszyn & 2.2 & 0.0011 & $\begin{array}{l}\text { fine and coarse-grained sands, } \\
\text { loams }\end{array}$ & $10^{-5}$ & 3.96 \\
\hline a & Ciszyca & 2.8 & 0.0014 & coarse-grained sands & $10^{-3}$ & 5.04 \\
\hline
\end{tabular}

* $1=2 \mathrm{~km} ;{ }^{* *}$ according to Darcy's equation.

In the analysed cross-sections (Table 1), fine-grained sands with the total aquatic volume coefficient of 0.3 prevail. On the sample unit section of the river channel ( 1 metre), the water table difference of 4.8 metres and filtration range $l=1000 \mathrm{~m}$, the volume of water filtered from the river channel to the alluvial valley was $720 \mathrm{~m}^{3}$. Based on those parameters, approximate filtration value from both banks on the 80-kilometre river channel section during the flooding of 1997 was calculated. It amounted to $\sim 116$ million $\mathrm{m}^{3}$ (Figs 3a-g), which represents a significant percentage of the losses in the volume of the flooding wave. If the same parameters were to be adopted during the highest rainfall rise of the Vistula in June 1962, the river channel filtration would amount to $>5 \%$ of the runoff. Broad and flat floodplain terraces with low hipsometric amplitudes, built from coarse-grained sands and gravels, provide optimum conditions for river bank filtration. On the other hand, factors promoting river channel filtration include the flattening of the flood wave and small longitudinal slope of the water table in the river valley. Such conditions can be found on the left bank, between the Jeziorka and the Wilanówka, and from Łomianki to Kazun. Below the Wilanówka, the river valley is particularly susceptible to alluvial water rises. The right river bank and the Vistula terrace from Świder to the boundaries of Warsaw, built from sandy alluvia and gravels, pose no barrier to the filtration of river channel water. However, filtration is largely restrained by a considerable hydraulic gradient of alluvial water caused by the steep steps of the river terraces. The left-bank scarp has a similar nature; it is built from poorly permeable Pliocene silts, which serve as a barrier to river channel filtration. The right bank between Dąbrówka Leśna and Dąbrówka 
Szlachecka, with a distinctly marked layout of terraces underlain with clayey sands and loams of low permeability is not conducive for remote river channel filtration. The northern, left-bank section of the valley from Kiełpin to Kazun is characterised by very good conditions for river water filtration to alluvial water. Flood embankments constitute a direct barrier to the flood water. However, damming the water high above the underground water level increases energy gradients and reinforces river channel filtration to the alluvia.

\section{SUMMARY}

To sum up, it should be said that quantitative assessment of the river bank filtration is extremely difficult and that is why the presented figures can be treated as merely an approximation. This very complicated process of water recharge occurring between the river channel and several waterbearing strata developed in the alluvia and having free and perched water tables caused by hydrodynamic pressure, is characteristic of the Vistula and the majority of large valleys of lowland rivers. The connection between underground water and the river channel provides for river recharge (both lateral and subchannel) from the ground during low-flow and medium water stages, while during high-water stages and floods it determines the course of filtration - water runoff from the river channel, thus temporarily increasing the valley retention. Those are the reasons why the river valleys should be protected. The valley bottoms and alluvial terraces are filled with alluvial water, which is important for the existence of riverside meadows, wetlands, riverside carr adding to the biodiversity of species. Furthermore, the valleys of great lowland rivers are extremely sensitive areas (ecotones) with special buffer properties. Due to point-source and local pollution of the valleys, underground water connecting with the channels of big rivers should be particularly protected. Their significance increases proportionally to the use of alluvial water.

\section{REFERENCES}

Bażyński J., 1996a, Eksploatacja wód z utworów oligoceńskich w rejonie Warszawy

[Use of Water from Oligocene Formations], Przeglqd Geologiczny, 44, No. 4.

B a żyńs ki J., 1996b., Woda poziomu oligoceńskiego na tle zaopatrzenia Warszawy w wodę do picia [Oligocene-aquifer Water and Warsaw's Supply of Potable Water], Przeglad Geologiczny, 44, No. 4.

B a ż y ń s ki J., 1997, Eksploatacja wód poziomu oligoceńskiego w Warszawie na tle zmian depresji regionalnej [Use of Oligocene-aquifer Water in Warsaw and the Changes in Regional Depression], [in:] J. Dowgiałło, A. Macioszczyk (eds), Oligoceńskizbiornik wód podziemnych regionu mazowieckiego, Ministerstwo Ochrony Srodowiska, Zasobów Naturalnych i Leśnictwa, Warszawa.

Biernacki Z., 1990, Wisła i jej dolina w środowisku przyrodniczym Warszawy [The 
Vistula and its Valley in the Natural Environment of Warsaw], [in:] Środowisko przyrodnicze Warszawy, PWN, Warszawa.

Gą s ow sk a G., 1998, Związek wód aluwialnych doliny z wezbraniem Wisły [The Correlation between Alluvial Water and Flooding of the Vistula], M.A. at Hydrology Department, Warsaw University.

Ka zimierski B., 1997, Badania hydrogeologiczne i zagospodarowanie oligoceńskiego zbiornika wód podziemnych - stan obecny i plany na przyszłość [Hydrogeological Studies and Development of the Oligocene Underground Water Reservoir - Status quo and Plans for the Future], [in:] J. Dowgiałlo, A. Macioszczyk (eds), Oligoceński zbiornik wód podziemnych regionu mazowieckiego, Ministerstwo Ochrony Środowiska, Zasobów Naturalnych i Leśnictwa, Warszawa.

Macios z c zyk T., 1988, System krążenia wód podziemnych niecki mazowieckiej jako podstawa optymalizacji gospodarowania regionalnymi zasobami wód podziemnych środkowej Polski. Sympozjum "Współczesne problemy hydrogeologii regionalnej" [Underground Water Circulation Systemin the Mazovian Basin as the Basis for Optimalisation of the Management of Regional Underground Water Resources of Central Poland. Conference on the Contemporary Problems of Regional Hydrogeologyl, Warszawa.

M a cios z c z y k T., 1996, Badania modelowe niecki mazowieckiej [Model Research of the Mazovian Basin], Przeglad Geologiczny, 44, No. 4

Macios zczyk T., 1997, System krążenia wód podziemnych w oligoceńskim zbiorniku niecki mazowieckiej [Underground Water Circulation System in the Oligocene Water Reservoir of the Mazovian Basin], [in:] J. Dowgiałło, A. Macioszczyk (eds), Oligoceński zbiornik wód podziemnych regionu mazowieckiego, Ministerstwo Ochrony Srodowiska, Zasobów Naturalnych i Leśnictwa, Warszawa.

Mi e rki e w i c z M., S a s i m M., 1998, Powódź opadowa w dorzeczu górnej Wisły w kwietniu 1998 r. [Rainfall Flood in the Upper Vistula Basin in April 1998], Gospodarka Wodna, No. 9.

Miesięczny Biuletyn Wód Gruntowych [Monthly Underground Water Bulletin], 1997, IMGW, Ośrodek Technicznej Kontroli Zapór - Zespól Wód Gruntowych, 3, Nos. 7-12.

P a z dro Z., 1983, Hydrogeologia ogólna [General Hydrogeology], Wydawnictwa Geologiczne, Warszawa.

Sarnacka Z., 1997b, Objaśnienia do szczegótowej mapy geologicznej Polski, arkusz Piaseczno 1:50 000 [Notes to the Detailed Geological Map of Poland, Piaseczno Sheet 1:50000], Wydawnictwa Geologiczne, Warszawa.

Sarnacka Z., 1990, Uwarunkowania geologiczne [Geological Considerations], [in:] Środowisko przyrodnicze Warszawy, PWN, Warszawa.

Ski b n i ew s k i L., 1959, Podział odpływu Wisły na powierzchniowy i gruntowy w okresie 1950-1954 [Surface and Ground Runoff of the Vistula Runoff in the Years 1950-1954], Wiadomości Stużby Hydrogeologicznej i Meteorologicznej, Wydawnictwa Komunikacji i Łączności, Warszawa.

Starkel L., 1994, Reflection of the Glacial-interglacial Cycle in the Evaluation of the Vistula River Basin, Poland, Terra Nova, 6.

Zuchiewicz W., 1998, Zróżnicowane tempo erozji rzecznej w Polskich Karpatach Zewnętrznych jako wskaźnik młodych ruchów tektonicznych. Mat. z konferencji "Neotektonika Polski - teraźniejszość i przeszłość" [Varied Pace of River Erosion in the Polish Carpathians as an Indicator of Recent Tectonic Movements. Proceedings from the conference "Poland's Neotectonics - the Present and the Past], X, Kraków. 